\title{
Osteossíntese de fratura diafisária do úmero com placa em ponte: Apresentação e descrição da técnica
}

\author{
Osteosynthesis of the humeral shaft fractures, with bridge plate
}

Bruno LIVANI', WILLIAM DIAS BELANGERO²

\section{RESUMO}

Os autores descrevem o método cirúrgico inédito para o tratamento das fraturas da diáfise do úmero, com placa colocada por técnica minimamente invasiva. Após estudos anatômicos, foram identificadas três acessos cirúrgicos pelos quais se pode introduzir uma placa na face anterior do úmero, sem risco de lesão vásculo nervosa. O acesso proximal se faz entre os múculos deltóide, lateralmente, e bíceps braquial, medialmente. Nas fraturas do terço médio o acesso distal é feito entre os músculos bíceps braquial e braquial com a placa introduzida de proximal para distal. Nas fraturas distais do úmero o acesso proximal é o mesmo, mas o acesso distal é o descrito por Kocher, com a placa introduzida de distal para proximal e fixada na face anterior da coluna lateral do úmero. O método aqui apresentado vem sendo utilizado desde junho de 2001, principalmente nos pacientes politraumatizados e polifraturados, por ser rápida, segura e por permitir que o paciente possa ser operado em decúbito dorsal horizontal. Além disso, não há necessidade de intensificador de imagem, ou mesmo aparelho de radiografia. Até o momento não foram observadas complicações vásculo nervosas nos 22 pacientes tratados.

Descritores: Fraturas do úmero; Fixação interna de fraturas; Placas óssseas; Diáfises

\section{INTRODUÇÃO}

O tratamento conservador continua sendo o tratamento de escoIha para as fraturas isoladas da diáfise do úmero(16). No entanto, o tratamento cirúrgico é apontado como a melhor opção ${ }^{(15)}$ nos pacientes obesos, nos pacientes com lesões vásculo-nervosas associadas e principalmente nos politraumatizados e polifraturados, cuja freqüência tem aumentado cada vez mais devido aos traumas de alta energia(3) $^{(3)}$, resultando em fraturas complexas, inclusive do membro superior. Nessas circunstâncias, os pacientes têm dificuldade de assumir a posição ortostática e de utilizar funcionalmente o membro superior fraturado, devido à presença de lesões associadas e devido ao grave comprometimento sistêmico, contra indicando assim o tratamento conservador ${ }^{(2,13)}$. Assim, o tratamento cirúrgico, realizado com redução aberta e fixação interna rígida (placa e parafuso), ou a foco fechado com estabilidade relativa (haste intramedular bloqueada), são os métodos mais aceitos na literatura ${ }^{(7,14)}$.

Procedimentos minimamente invasivos, como têm sido preconizados para o tratamento das fraturas dos membros inferiores $(1,8,11,12)$, poderiam ser uma opção atraente para o tratamento dessa fraturas, principalmente em pacientes graves. Das opções possíveis, a haste intramedular bloqueada a foco fechado é a alternativa mais indicada. No entanto, estudos multicêntricos randomizados que comparam o desempenho das hastes bloqueadas a foco fechado com as placas a foco aberto, têm mostrado que não há vantagens com relação às hastes, já que houve significativamente maior número de casos com

Trabalho realizado no Departamento de Ortopedia e Traumatologia Faculdade de Ciências Médicas - Universidade Estadual de Campinas

1 - Mestre em Cirurgia pela FCM - UNICAMP

2 - Professor Doutor do Departamento Ortopedia e Traumatologia da FCM - UNICAMP

Endereço para correspondência: Rua Vicente Porto no. 208, Barão Geraldo, 13085-895 - Campinas/SP, e-mail: brunolivani@hotmail.com Telefone: 01937887750 e 37887715

Trabalho recebido em 17/09/03. Aprovado em 09/04/04.

\section{SUMMARY}

The authors describe for the first time ever a minimally invasive plate osteosythesis for the treatment of the humeral shatf fractures. After anatomic human cadaver's studies, it was identified three surgical approaches for plate percutaneous insertion on the anterior surface of the humerus without vascular and nervous injury. The proximal approach is between the biceps and deltoid muscles. The distal approach for medial third fractures is between the biceps brachialis and brachialis muscles. The plate is inserted from the proximal to distal direction. For distal fractures, the proximal approach is the same described by Krocher, with the plate inserted from distal to proximal and fixed on the anterior surface of the lateral column of the humerus. This method has been used since June/2001 mainly for the treatment of multiple trauma patients, allowing other surgical procedures, and it has been showed very efficient. The patient is operated in DHD without image intensifier or $x$ ray apparatus. Until the moment, 22 patients have been treated without vascular or nervous complications.

Key words: Humeral fractures; Fracture fixation, Internal; Bone plates; Diaphysis.

\section{INTRODUCTION}

The traditional treatment is still used to the humeral shaft isolated fractures ${ }^{(16)}$. However the surgical treatment is shown as the best choice ${ }^{(15)}$ in obese people, patients with vascular or nervous injuries and mainly the ones with the multiple traumas, whose frequency has increased due to severe traumas ${ }^{(3)}$, result in complex fractures, mainly the upper limbs. Under the circumstances the patients have difficulty in assuming the orthostatic position and of using successfully the upper limbs fractured because of the injuries and also systemic healthy, not indicated the conventional treatment ${ }^{(2,13)}$. The surgical treatment, made with open reduction and tough internal fixation (plate and screws) or with the close focus with relative stability (blocked intramedular stalk), are the most used method ${ }^{(7,14)}$

Procedures minimally invasive are suggested to the lower limbs treatment ${ }^{(1,8,11,12)}$ could be a very interesting choice fractures treatment, mainly in severe clinical patients. However, multicentered random studies that compare the performance of the blocked stalks to close focus with the plates to open focus, has shown some advantages towards the stalks, as its has been large number of cases with no retard of joining, pain dysfunction of the shoulder and re-operations in the patients treated with stalks. In addition, there was no important inter-operatory bleeding in in the surgery time procedure ${ }^{(5)}$.

Technically, against the stalks there is still the fact that these

Work performed at Orthopedics and Traumatology Department of FCM UNICAMP) - State University of Campinas

1 - Master in Surgery FCM - UNICAMP

2 - PhD Professor of the Orthopedics and Traumatology Department of FCM - UNICAMP

Address: Rua Vicente Porto, 208, Barão Geraldo - 13085-895 - Campinas -São Paulo

E-mail: brunolivani@hotmail.com - phone: 01937887750 and 37887715 
retardo de união, de dor, de disfunção do ombro e de reoperações no grupo dos pacientes tratados com as hastes. Além disso, não houve diferença significativa quanto ao sangramento intra-operatório e o tempo de duração do procedimento cirúrgico ${ }^{(5)}$. Tecnicamente, contra as hastes existe ainda o fato de que essas necessitam do uso do intensificador de imagem e do posicionamento do paciente em decúbito lateral, ventral ou semi-sentado, o que pode dificultar o tratamento de outras fraturas ou de lesões associadas nos pacientes polifraturados ou politraumatizados ${ }^{(14)}$.

Tendo em vista essas considerações, os autores apresentam o método da placa em ponte para o tratamento cirúrgico das fraturas diafisárias do úmero, com técnica minimamente invasiva.

\section{MATERIAL E MÉTODOS}

\section{Considerações sobre a técnica cirúrgica:}

Quando se pensa em introduzir uma placa com técnica minimamente invasiva para o tratamento das fraturas da diáfise do úmero, a primeira questão que se coloca é como evitar a lesão do nervo radial. Revendo-se a anatomia do braço e realizando-se estudos em cadáveres, foram estabelecidas as vias de acesso para esse procedimento, sem riscos de lesão do nervo radial, ou de outras estruturas neurovasculares, além de se definir marcos anatômicos para orientar a redução dos fragmentos ósseos. Estudando-se as vias de acesso anterior ou ântero-lateral descritas por Thompson em 1918 e Henry em $1966{ }^{(4)}$, pôde-se definir um corredor livre de estruturas vásculonervosas na face anterior do úmero. Nessa face situa-se o músculo braquial, que é inervado na sua porção lateral pelo nervo radial e na sua porção medial pelo nervo músculocutâneo. Esta particularidade anatômica permite que o mesmo possa ser divulsionado longitudinalmente em toda a sua extensão, sem comprometimento da sua função. As únicas estruturas potencialmente em risco nessa abordagem são o nervo cutâneo lateral do antebraço, ramo sensitivo do nervo musculocutâneo situado entre os músculos bíceps braquial e o braquial e o nervo radial entre os músculos braquial e o braquioestilorradial no terço distal do braço $(6,10)$.

\section{Apresentação da técnica operatória:}

O procedimento é realizado com o paciente em decúbito dorsal horizontal, em mesa operatória convencional, com o cotovelo semifletido (Figura 1). Foram definidas três vias de acesso: uma proximal e duas distais, dependendo da localização da fratura, se médio-diafisária ou distal.

O acesso proximal é feito entre os músculos bíceps braquial, medialmente, e o músculo deltóide, lateralmente, junto com a veia cefálica, com 3,0 a 5,0 cm de comprimento. Para as fraturas do terço médio, o acesso distal com o mesmo comprimento é feito entre os músculos bíceps braquial e o braquial, abaixo do foco. Neste espaço visualiza-se facilmente o nervo cutâneo lateral do antebraço, situado medialmente e superiormente ao músculo braquial (Figura 2). O músculo braquial é dividido longitudinalmente para expor a face anterior do úmero (Figura 3). Nas fraturas do terço distal utiliza-se a via descrita por Kocher (4) para abordar a coluna lateral do úmero, com dissecção sub-periosteal da crista supra-epicondilar lateral do úmero e afastamento conjunto dos músculos braquioestilorradial e extensor longo radial do carpo e do nervo radial anteriormente (Figuras $4 \mathrm{a}, 4 \mathrm{~b}$ e $4 \mathrm{c}$ ). O afastamento deve ser feito sempre sem o uso de alavancas ou afastadores do tipo $\mathrm{Ho}$ hmann para se evitar a lesão do nervo radial. Para as fraturas do terço médio, utilizam-se placas retas DCP stalks need the intensifier image use and the position of the patient in lateral, ventral and semi-sitting, decubitus what can cause difficulty the others fractures treatment to be associated with multiple fractured and multiple traumatized patients ${ }^{(14)}$.

Taking these into considerations, the authors show the minimally invasive method for humeral shaft fractures surgical treatment.

\section{MATERIALS AND METHODS}

\section{About the surgical technique}

When a minimally invasive plate osteossynthesis is thought to be used in humeral shaft fractures, the first thing to avoid is the nervous radialis injury. Studying and seeing the human cadavers again, the approach for this procedure with no nervous radialis injury, or any other nervous vascular structures, defining the anatomical reduction of the bone fragments the anterior or posterior lateral surface described by Thompson in 1918 and Henry in $1966{ }^{(4)}$, a free approach structure on the anterior surface of the humerus, which is full of nervous, on this surface is the brachialis muscle, which is innervated at the lateral surface by the radialis nervous and in the region of the medial by the cutaneous muscles. This anatomical detail allows the same to happen in the widespread longitudinal region, without harming its function. The only potentially risky structures of this study is the cutaneous lateral nervous of the forearm, sensitive branch of the cutaneous muscle located between the biceps brachialis muscles, brachialis and the radialis nervous between the brachialis muscles and the brachialisstyloradialis of the third distal of the $\operatorname{arm}^{(6,10)}$.

\section{The operatory technique presentations}

The procedures are done with the patient in horizontal dorsal decubitus on a conventional operatory table, with the elbows semi-flexed (Figure 1). Three approaches were defined, one proximal and two distal, depending on the fracture local, if medium or distal shaft.

The proximal approach is done between the biceps brachialis muscles, medially, and the deltoids muscle, laterally together with the cephalic vein, with 3,0 to $5,0 \mathrm{~cm}$ length. For the median third fractures, the distal approach with the same length is done between the biceps brachialis muscles and the brachialis, below of the focus. In this space the lateral cutaneous nervous of the forearm is easily seen, situated medially and superiorly to the brachialis muscle (Figure 2). The brachialis muscle is divided longitudinally to show the anterior surface of the humerus Figure 3. In the third distal fractures the approach used by Krocher ${ }^{(4)}$ is to abort the lateral column of the humerus, with subperiosteos dissection of the crest of superepycondilus lateral humerus and distance of the set of muscles, the brachialis stylusradial and extensor radialis longus of the carpus and the radial nervous on the anterior surface (Figures $4 a, 4 b$ and 4c) The distance must be done with the use of a lever or separation apparatus of the Hohmann in order to avoid the radial nervous injury. For the third median fractures, straight plate DCP is used, normally with twelve punctures, of big fragments, which does not need mouldling, as the anterior surface of the humerus plane. The plate is inserted from distal to 
estreitas, em geral com doze furos, de grandes fragmentos, que não precisam ser moldadas, já que a face anterior do úmero é plana. A placa é introduzida de proximal para distal e fixa-se primeiro o último parafuso distal, deixando-o relativamente frouxo para permitir a adaptação da mesma sobre o osso. Em seguida, abduz-se o braço em torno de $60^{\circ}$ para se corrigir o desvio em varo e com leve tração roda-se o fragmento distal, de forma que o eixo bicondilar fique em um plano ortogonal em relação ao tendão longo do bíceps braquial, colocando-se a seguir o primeiro parafuso proximal (Figura 5). Segue-se, então, com a colocação dos demais parafusos, num total de dois (preferencialmente em furos alternados) ou três em cada fragmento. Para as fraturas distais utiliza-se o mesmo implante, que deve ser moldada na sua porção distal para se adaptar na coluna lateral do úmero, evitando-se o bloqueio da fossa coronóide ou da olecraneana (Figura 6). Nessas fraturas a placa é introduzida de distal para proximal, a fim de se evitar falso trajeto e lesão do nervo radial na sua porção distal que, nesse acesso, encontra-se localizado anteriormente à placa (Figura 7).

O fechamento da ferida é realizado de maneira habitual e não há necessidade do uso de dreno de aspiração, nem de imobilização externa. Não há necessidade do uso do intensificador de imagens ou de controles radiográficos durante o procedimento cirúrgico. Imediatamente após a cirurgia, o paciente é orientado a movimentar livremente as articulações do ombro e do cotovelo e a utilizar o membro operado para atividades de vida diária, tais como se alimentar e realizar higiene pessoal. Os pontos de sutura são retirados rotineiramente entre $010^{\circ}$ e $15^{\circ}$ dia pós-operatório.

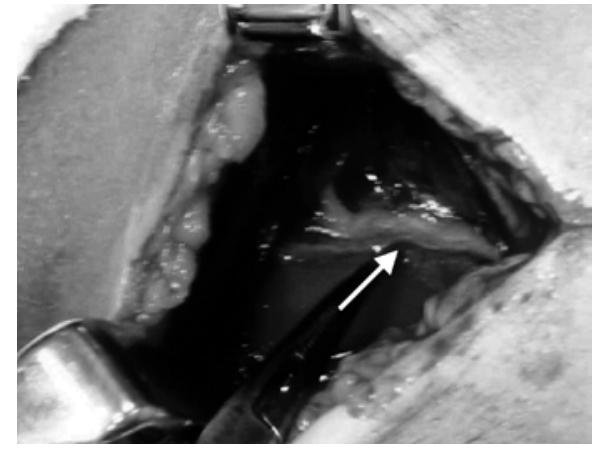

Figura 2 - Foto intraoperatória mostrando o nervo cutâneo lateral do antebraço (seta) sobre o a face anterior do músculo braquial

Figure 2 - Inter-operatory photo showing a lateral cutaneous nerve of the forearm (arrow) on the anterior surface of the brachialis muscle.

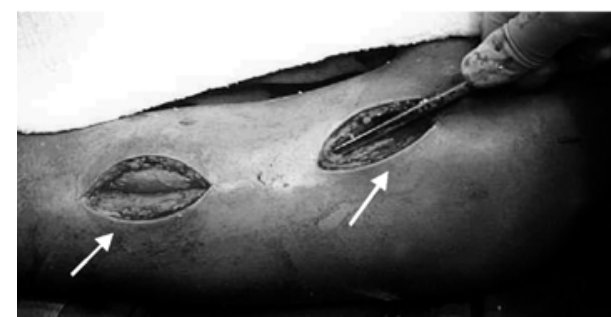

Figura 3 - Foto intraoperatória de fratura do terço médio do úmero. Nota-se a incisão proximal (seta) entre os músculos deltóide e bíceps e a incisão distal

(seta) entre os músculos bíceps e braquial. $A$ introdução da placa está sendo feita de proximal para distal

Figure 3 - Interoperatory photo of the median third fracture of the humerus. It is noticeable the proximal incision (arrow) between the deltoids and biceps muscles and the distal incision (arrow) between the brachialis and biceps muscles. The inserting of the plate is being done from the proximal to distal directions. proximal, first the distal screw is the last to be fixed, let it slightly loosen to allow its adaptation to the bone. Next, abduct the arm around $60^{\circ}$ to correct the deviation in varus and smooth traction spin the distal fragment, as long as the biochondilar axis stays in a orthogonal plane in relation of the biceps brachialis longus of the tendon, inserting, then the first proximal screw (Figure 5), Then the next screws, total of two (preferable with alternate punctures) or three in each fragment. For the distal fractures the same implant is used, which must be mouldled in its distal region to be fit in the lateral column of humerus, avoiding the blocking of the coronoid fossa or the olecranon (Figure 6). In this case the place is inserted from distal to proximal direction, to avoid wrong trajectory and the nervous radialis injury in the distal region, in this approach is located in the anterior surface to the plate (Figure 7).

The injury healing is used in a usual way and there is no need of the use of an aspirator drain, neither external immobilization. There is no need of the image intensifier or the radigraphs control during the surgical procedure. Sooner after the surgery, the patient if allowed to move freely the joints of the shoulder and elbow and use the operated limb for daily activities, such as. feeding and personal hygiene. The stitches of the suture are removed routinely between $10^{\circ}$ and $15^{\circ}$ days post operatory.

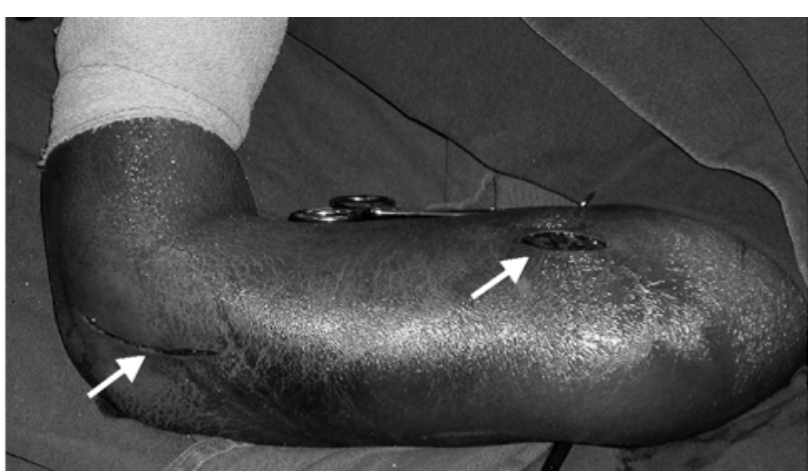

Figura 4a - Foto intraoperatória de fratura diafisária distal do úmero. Nota-se a incisão proximal (seta) entre os músculos deltóide e bíceps e a incisão distal (seta) segundo a via de acesso descrita por Kocher.

Figure 4a - Interoperatory photo of the distal shafts of humerus. It is noticeable the proximal incision (arrow) between the deltoids and biceps muscles and the distal incision (arrow) according to the approach described by Kocher.

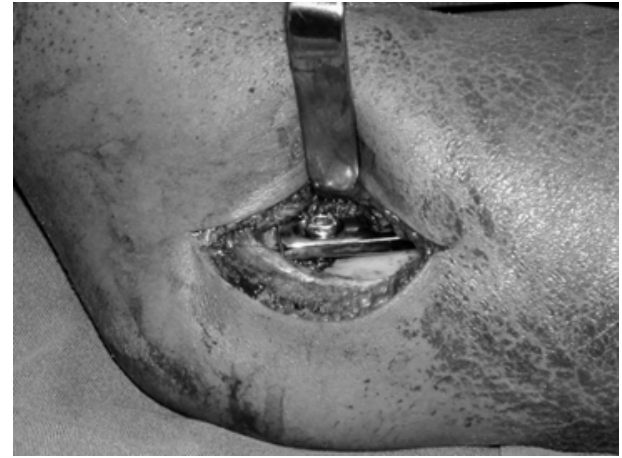

Figura $\mathbf{4 b}$ - Foto intraoperatória de fratura diafiisária distal do úmero. Nota-se a incisão distal, segundo a via de acesso descrita por Kocher, com a exposição da face anterior da coluna lateral do úmero e da placa já fixada

Figure $\mathbf{4 b}$ - Interoperatory photo of the distal shafts of humerus fracture. It is noticeable the distal incision, according to the approach described by Kocher, with the anterior surface exposition of the lateral column of the humerus and the plate already fixed.

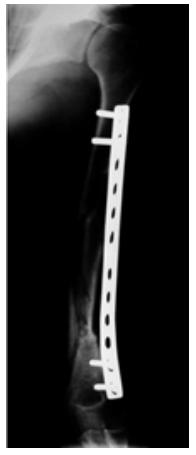

Figura 4c - Radiografia do pós-operatório tardio (um ano) de uma fratura diafisária distal consolidada

Figure 4c - Radiography of the late pot operatory (one year) of a distal shafts fracture consolidated. 


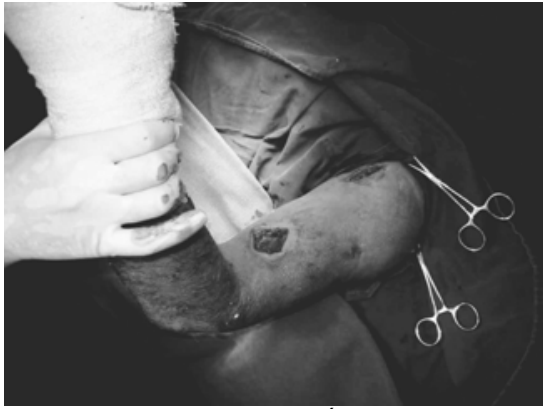

Figura 5 - Foto intraoperatória com o braço abduzido em torno de $60^{\circ}$ para correção do varo do fragmento distal, antes da fixação do fragmento proximal.

Figure 5 - Interoperatory photo with the arm abducted around $60^{\circ}$ to correct the distal varus fragment, before the fixation of the proximal one

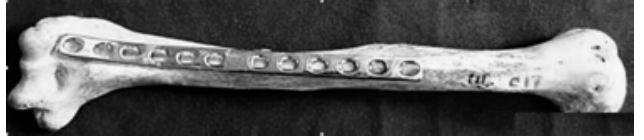

Figura 6 - Placa DCP de grandes fragmentos assentada na face anterior do coluna lateral do úmero para o tratamento de fraturas diafisárias distais

Figure 6 - The big DCP plate fragments sitting on the anterior surface of the lateral column of humerus to the distal shafts fractures treatment.

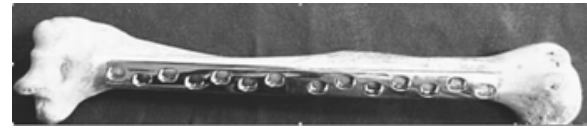

Figura 8 - Placa DCP de grandes fragmentos assentada na face anterior do úmero para o tratamento de fraturas médio diafisárias Figure 8 - The big DCP plate fragments sitting on the anterior surface of the humerus to the median shafts fractures treatment.

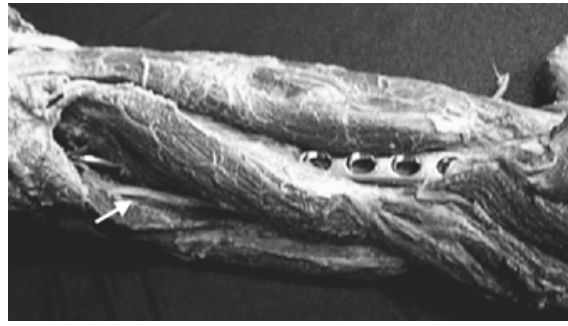

Figura 7 - Placa situada entre os músculos bíceps e braquial e nervo radial (seta) situado num plano mais profundo entre os músculos braquial e braquio estilo radial

Figure 7 - Place located between the biceps and brachialis muscles and radialis nervous (arrow) situated in a deeper plane between the brachialis muscles and brachial stylus radialis.

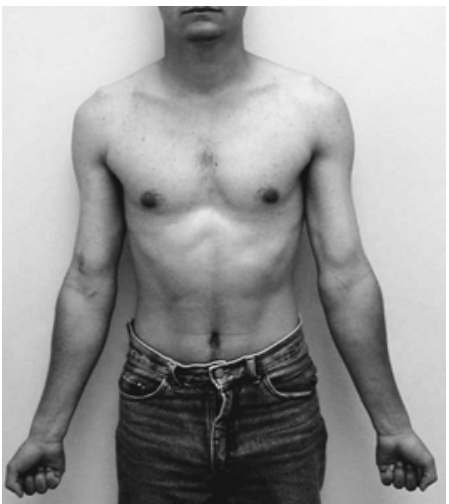

Figura 9a - Foto do paciente no pós-operatório tardio (18 meses), mostrando ângulo de

carregamento e extensão normais do cotovelo

Figure 9a - the late post operatory photo of the patient (18 months), showing loading angle and normal extension of the elbow.

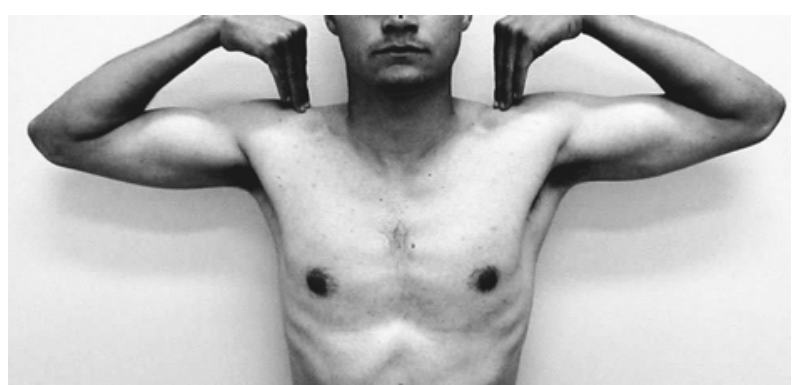

Figura 9b - Foto do paciente no pós-operatório tardio (18 meses), com flexão completa do cotovelo e abdução e rotação externa dos ombros simétricas

Figure $\mathbf{9 b}$ - the late post operatory photo of the patient (18 months), with complete flexion of the elbow and abduction and external rotation of the symmetric shoulders.

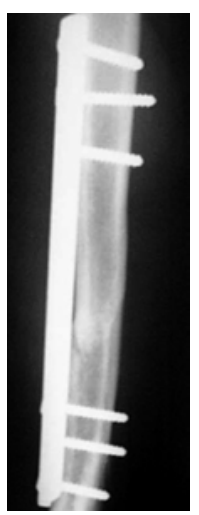

Figura 9c - Radiografia do pósoperatório tardio (18 meses) de uma fratura médio diafisária tratada pela técnica da placa em ponte consolidada

Figure 9c - Radiography of the late post operatory (18 months) of a median shaft fracture treated done with the technique of the plate bridge consolidate.

\section{DISCUSSÃO}

Apesar do tratamento conservador continuar sendo o método de escolha para as fraturas isoladas da diáfise do úmero(16), nos pacientes em que há necessidade do tratamento cirúrgico os métodos disponíveis não são isentos de riscos e complicações e a maioria dessas ocorrem pela própria técnica e pela exposição cirúrgica da fratura ${ }^{(7)}$. A partir década de 80 , os procedimentos minimamente invasivos tornaram-se comuns e a placa em ponte destacou-se no tratamento das fraturas dos membros inferiores, mas sem se encontrar relatos da utilização para as fraturas da diáfise do úmero. A grande contribuição deste estudo é demonstrar que é possível tratar as fraturas da diáfise do úmero por técnica minimamente invasiva, com a placa sendo colocada por dois pequenos acessos, sem risco de lesão iatrogênica do nervo radial, complicação descrita no tratamento dessas fraturas por via aberta ${ }^{(7)}$. A utilização do acesso anterior,

\section{DISCUSSION}

Despite the traditional method continue to be the chosen method for isolate fractures of the shafts of humerus ${ }^{(16)}$, in patients who need surgical treatment, the available methods are not free of risks and complication, and most of them occur because of this technique or the submission to the surgery ${ }^{(7)}$. From the 80 decade on, the procedure shortly invasive became common and the plate became outstanding in the treatment of the lower limbs fractures, but not for the shafts humerus fractures. The main purpose of this study is to show the possibility of treating shafts humerus fractures by minimally invasive technique, using two approaches to insert the plates, with no risk of iatrogenic injury of the radialis nervous, complication described in the treatment of these fractures by open approach. The use of the anterior surface approach, inserting the plate in the anterior 
com a colocação da placa na face anterior do úmero, é uma excelente solução para se evitar a lesão do nervo radial que circunda a região medial, posterior e lateral da diáfise desse osso. Coincidentemente, a face anterior do úmero, por ser plana, permite que a placa deslize facilmente sobre sua superfície e pelo foco de fratura, adaptando-se perfeitamente à topografia desse osso (Figura 8).

Quanto ao desempenho da técnica, os pacientes se beneficiam não só da mobilização precoce e ativa do membro, devido à pequena agressão cirúrgica, como também da estabilidade obtida, que é suficiente para suportar os esforços das atividades de vida diária, eliminar a dor e propiciar a rápida recuperação do arco de movimento articular do ombro e cotovelo (Figuras 9a, 9b e 9c)

Esta técnica abre uma nova perspectiva para o tratamento das fraturas da diáfise do úmero, principalmente nos pacientes politraumatizados ou polifraturados. No entanto, a técnica não está indicada para os pacientes com lesão do plexo braquial, que não consigam realizar a flexo extensão ativa do cotovelo. Teoricamente, fraturas associadas à lesão do nervo radial, fraturas patológicas e fraturas expostas grau III-B ou III-C também não devem ser tratadas por esse método. Nas fraturas com lesão do nervo radial e padrão clássico descrito por Holstein and Lewis ${ }^{(9)}$ o nervo pode estar aprisionado entre os fragmentos ósseos, sendo necessário portanto a abordagem direta do foco de fratura. Já nas fraturas patológicas ou com pouco estoque ósseo (tumores, doenças metabólicas ou osteoporose) a qualidade do osso pode comprometer a fixação dos parafusos e, portanto, o resultado final do tratamento. Já com relação às fraturas expostas III-B e III-C, o fixador externo é ainda a opção mais segura até a resolução das lesões de partes moles, para só então se indicar o tratamento definitivo mais adequado.

\section{CONCLUSÃO}

Pode-se concluir que a técnica inédita aqui apresentada, além de poder ser executada com relativa facilidade e segurança, tem como principal vantagem a possibilidade de ser feita em decúbito dorsal horizontal, sem instrumental cirúrgico sofisticado e sem o uso do intensificador de imagem ou aparelho de radiografia. Esta técnica está indicada para o tratamento de pacientes polifraturados ou politraumatizados, nos quais há necessidade da fixação de fraturas concomitantes em outros segmentos e da realização de procedimentos cirúrgicos por outras especialidades. surface of the humerus, is an excellent choice to avoid the radial nervous injury that rounded the medial, posterior and lateral region of the shafts of this bone. Coincidently, the humerus anterior surface, due to be plane, allows the plate slides easily on the surface and the focus of fracture, adapting perfectly to the topography of this bone (Figure 8)

About the technique performance, the patients not only took advantage of the previous and active immobilization of the limb. due to the slight severity of the surgery, but also with the obtained stability, that is enough to sustain the efforts of the daily activities, relieving the pain and fast recovery of the arch joint movement of the shoulder and elbow (Figures 9a, 9b, 9c)

This technique is a new perspective to the shafts humerus fractures treatment, especially in multiple traumatized and multiple fractured patients. However this technique is not suggested for patients with plexus brachialis injury, who were not able to do the active flexion extensive of the elbow. Theorically, fractures associated to radialis nervous injury, pathological fractures and exposed fractures of IIIB or IIIC degrees neither can be treated using this method. In radial nervous injury fractures and classical pattern described by Holstein and Lewis ${ }^{(9)}$, the nervous can be tied between the bones fragments, being necessary the direct approach of focus of the fracture. In the pathological fractures or with little bone storage (tumors, metabolic illness or osteoporoses) the quality of the bone can reject the fixation of the screws, and then, the end of the treatment. About the exposed fractures III-B and III-C, the external fixer is still the safer choice until the resolution of the injuries of the smooth regions; therefore prescribe the definite treatment as more appropriate.

\section{CONCLUSION}

The technique shown, besides being done with certain facility and security, has as main advantage of the possibility to be made in dorsal horizontal decubitus, with no need of sophisticated surgical instruments and neither they use of an intensifier image or radiographic apparatus. This technique is advised to multiple traumatized and multiple fractured patients, where there is need of the fixation of the concomitant fractures in other fragments and surgical procedures for other specialties.

\section{REFERÊNCIAS BIBLIOGRÁFICAS}

1. Belangero WD. Princípios Gerais de Osteossíntese e Fixação Biológica das Fraturas. In: Baldy FR. Fraturas. Campinas, Autores Associados, 2000:23-28.

2. Bell MJ, Beauchamp CG, Kellam JK, McMurtry RY (1985). The Results of plating humeral shaft fractures in patients with multiple injuries. The Sunnybrook experience. J Bone Joint Surg, 67-B:293-296.

3. Christensen S (1967). Humeral shaft fractures. Operative and Conservative Treatment. Acta Chir Scand, 133:455-460.

4. Crenshaw AH. Campbell's Operative Orthopaedics, 7th edn. The CV Mosby, St. Louis, 1987, Vol. 1:85-87

5. Farragos AF, Schemitsch EH, McKee MD (1999) Complications of intrameduIlary nailing for fractures of the humeral shaft: A review. J Orthop Trauma, 13(4):258-267

6. Gardner E, Gray DJ, O'Rahilly R. Anatomia: Estudo regional do corpo humano. 4th edn. São Paulo, Guanabara Koogan, 1988:122-129.

7. Heim D, Herkert F, Hess P, Regazzoni P (1993). Surgical treatment of humera shaft fractures. The Basel experience. J Trauma, 35(2):226-231.

8. Heitemeyer U, Kemper F, Hierholzer G (1987). Severely comminuted femoral shaft fractures: treatment by bridging-plate ostheosynthesis. Arch Orthop Surg 106:327-330
9. Holstein A, Lewis GB (1963). Fractures of the humerus with radial nerve paralysis, J Bone Joint Surg, 45-A (7): 1382-1388.

10. Hoppenfeld S, deBoer Piet. Vias de acesso cirúrgico em ortopedia. Vias de acesso Anatômico, São Paulo, Manole, 1990:47-75.

11. Hungria Neto JS (1996). Fraturas diafisárias do fêmur. Ainda há indicação para uso de placas? Rev Bras Ortop, 31:444-448.

12. Krettek C, Schandelmaier P, Miclau T, Tscherne H (1997). Minimally invasive percutaneous plate osteosynthesis (MIPPO) using the DCS in proximal and distal femoral fractures. Injury, 28(1):S20-S30.

13. Packer JW, Foster RR, Garcia A, Grantham AS (1972). The Humeral Fracture with Radial Nerve Palsy: Is Exploration Warranted? Clin Orthop Rel Res, 88:34 38

14. Rommens PM, Blum J, Runkel M, Degreif J (1999). Interlocked nailing of humeral shaft fractures with the Unreamed Humeral Nail (UHN). Injury, 30:S C64-S-C73.

15. Ruedi T, Moshfegh A, Pfeiffer KM, Allgower M (1974). Fresh fractures of the shaft of the humerus. Conservative or operative treatment? Reconstr Surg Traumat, 14:65-74.

16. Sarmiento A, Latta LL. Tratamento Funcional Incruento de las Fracturas. Buenos Aires, Panamericana, 1987:498-548. 